\title{
FDI and export linkage revisited: The case of Bangladesh
}

\author{
Muhammad Shariat Ullah, $\mathrm{PhD}^{\mathrm{a}}$, Farida Yasmeen ${ }^{\mathrm{b}}$ \\ a Associate Professor, Department of Management, University of Dhaka. \\ b Junior Research Fellow and Research Assistant, Bangladesh Institute for Research, Dhaka, Bangladesh. \\ *Corresponding author's email: shariat@du.ac.bd
}

\author{
H I G H L I G H T S: \\ 1. The effect of foreign direct investment on export has been studied for Bangladesh. \\ 2. Study window ranges from $1970-2010$. \\ 3. Panel estimation techniques have been used within widely used gravity model set up. \\ 4. Study result suggests that trade and factor flows act as complements indicating a positive role of FDI on export.
}

\section{Article History}

Received: 20-01-2014

Accepted: 26-02-2014

Available online: 28-02-2014

Keywords:

Bangladesh;

Complements and substitutes;

Export;

Foreign direct investment.

JEL Classification:

F13; F23.

DOI: http://dx.doi.org/10.18533/jefs.v2i01.49

(C) 2014 The Authors. This is an open access article under the terms of the Creative Commons Attribution License 4.0, which allows use, distribution and reproduction in any medium, provided the original work is properly cited.

\subsection{Introduction}

Foreign direct investment (FDI) is the primary vehicle of economic openness upon which the wave of globalization has been sweeping across the world. Alongside the conventional pressure for localization, many other contemporary factors like cost pressure, location economies, and FDI friendly policy of the host countries, induce firms either to dislocate or make new investments in other countries. The growing trends of firms' FDI decision are to invest in emerging economies. In order to attract more and more FDI, host countries, particularly the LDCs; tend to be more and more open and FDI friendly.

As an LDC country, economic policy of Bangladesh since the early 1990s has placed top priority on gradual opening of external sector through export promotion and FDI attraction. Increased liberalization stimulated export growth but at a lower rate than import growth that resulted in growing trade imbalances for the country. Macro-economic instability has been worsened in the year 2011 and continues in similar trend due to decrease in export growth, rise in import growth, slow growth in manpower export and high rates of inflation. Under this scenario, FDI could play the most vigorous role by strengthening firm competiveness though spillover effect that could also stimulate export. However, spill-over effects from FDI could not be evaluated in the absence of firm level data. This paper therefore, 
focuses on the role of FDI in stimulating aggregate export flows from Bangladesh. The remainder of the study is organized as follows: Section 2 describes trade and investment patterns Bangladesh; Section 3 reviews the literature on FDI-export linkage; Section 4 presents methodology and findings; and finally, Section 5 provides a conclusion.

\subsection{Trade and investment patterns in Bangladesh}

\subsection{International trade patterns}

International trade (export and import) exhibited an upward trend in the economy of Bangladesh over time. Share of total trade to GDP grew from 19\% to 42\% between 1980 and 2010, an indicator of increased openness as well as the growing importance of the external sector in the economy. The volume of trade has begun to rise substantially since the second half of the 1990s. Between 1990 and 2010, export increased by 8.8 folds, while imports grew by 7.6 folds. Overall, Bangladesh achieved highest export growth during the 1990s. However, current account of Bangladesh was always in deficit and widened over time as is evidenced in Fig.1. Trade deficits increased from US\$1820 million to US $\$ 27,771$ million from 1980-2010. This implies that healthy growth of exports also prompted rapid rise in imports due to absence of downstream industrial development. During the periods of 1981-1990, 1991-2000 and 2001-2010; average growth rates of exports were $8.6 \%, 13.1 \%$, and $10.7 \%$ compared to $3.8 \%, 10.0 \%$, and $12.9 \%$ average growth in imports. Thus, the current account has experienced a more precarious condition over the decade of 2001-2010 since growth of import exceeded the export growth during that period.

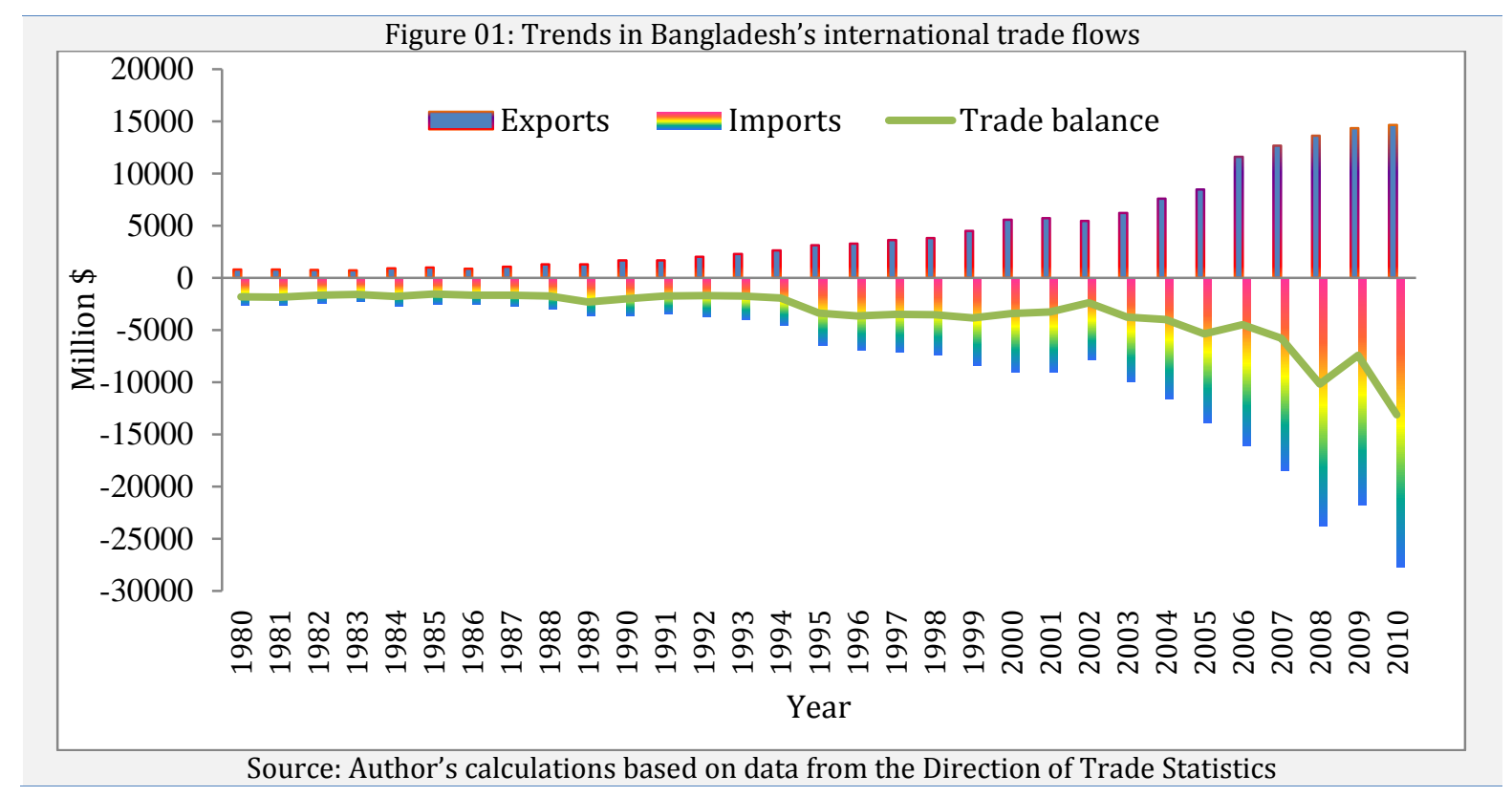

\subsection{Patterns of inward FDI}

In spite of its open door policy towards FDI since the 1980s and booming FDI inflows in Asia through the 1990s and 2000s; Bangladesh remains one of the least performers in attracting FDI in the regions. Fig. 2 highlights two decades' FDI inflows in Bangladesh. Until the middle of the 1990s, operations of foreign firms by direct investment were almost non-existent. Very negligible amount of FDI at a rising trend began to flow from the middle of the 1990s. Nonetheless, inward FDI dropped in the early 2000s. From 2005, volume of FDI inflow increased but sharply fluctuated between years. In its lifetime, Bangladesh could fetch annual FDI of US\$ 1 billion only once. As a consequence of little success in FDI attraction, role of FDI in Bangladesh economy has been quite negligible.

Figure 02: Trends for inward FDI in Bangladesh: 1990-2010 


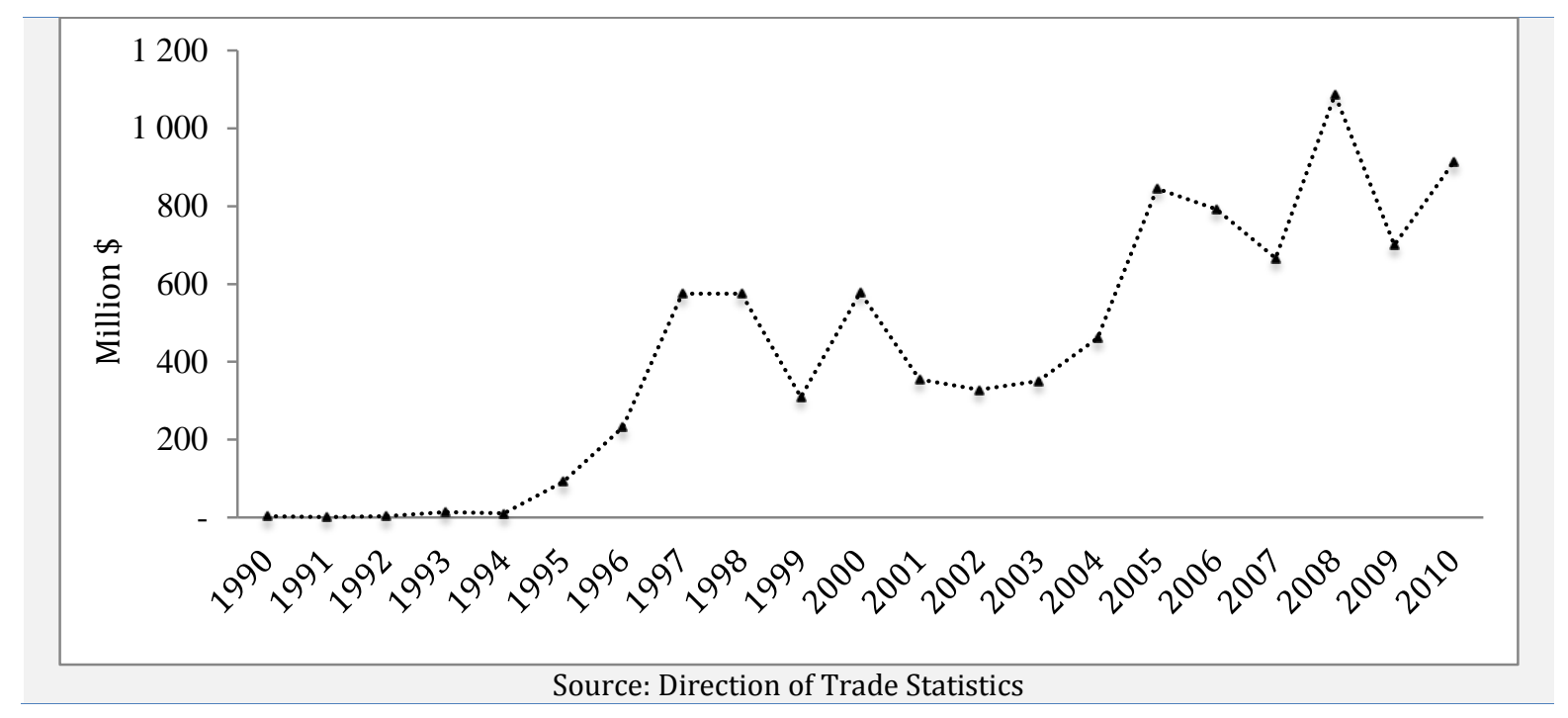

\subsection{Literature on FDI and export linkage}

Though not unanimous, it is apparent that there are significant interactions between trade and factor mobility. Mundell (1957) postulates that international trade in goods and factor mobility is substitutes because more of one leads to less of the other. A rise in international trade lowers the potential mobility of factors, while international mobility of factors lowers the volume of trade between nations.

The assertions that international trade and factor mobility are substitutes follow from Paul Samuelson's advancement of the Factor-Price-Equalization theorem which states that international trade brings about equalization in earnings for homogenous factors across nations which is corollary to Heckscher-Ohlin trade theory. The logic behind this idea is that as long as relative factor prices differ between countries, same happens to commodity prices, and trade continues to rise. Thus, international trade continues to expand until relative commodity prices and relative factor prices are exactly equal between nations. This intuition is corollary to the $\mathrm{H}-\mathrm{O}$ theorem of trade and is commonly referred to as $\mathrm{H}-\mathrm{O}$-S theorem which holds only of assumptions of the $\mathrm{H}-\mathrm{O}$ theorem, as such perfect competition in all commodity and factor markets and constant returns to scale. Thus, the essence of the H-O-S theorem is that trade acts as substitutes for the international mobility of factors of production in its effect on factor prices. In the product life cycle theory (PLC), Vernon (1966) also postulates a substituting relationship between FDI and trade. Dunning (1977) argued that exports and FDI are fundamentally substitutes.

Another strand of literature is the 'new trade theory' that emerged in the 1980s. Under this theory, FDI are categorized into two patterns: vertical and horizontal. The new trade theorists argue that the relationship between FDI and trade depends on the pattern of FDI, i.e. vertical or horizontal. Under the form of vertical FDI, investors disperse value-adding activities across the locations which are abundant with the required factors of production. In this case, each foreign facility serves as hub for serving the global market which in turn, boosts host country's export. In essence, there is likely to be a complementary relationship between trade and vertical form of FDI. On the contrary, MNEs undertake horizontal FDI in order to serve the local markets due to high barriers or costs of entry from international source of production. In some cases, this form of FDI is also known as tariff-jumping FDI. Under such circumstance, FDI tends to reduce trade and thus, there is substituting relationship between horizontal FDI and trade. Markusen (1983) argued that factor movements could give rise to trade, if it was based not on relative factor difference but on external economies of scale and different production technologies.

Thus, it appears that there exist two patterns of relationship between FDI and trade flows: complements and substitutes. These two simple patterns of relation between trade and FDI are in contrast with empirical studies (Pain and Wakelin, 1998) that show that the relationship is complex (Pontes, 2005). Xuan and Xing (2008) evidence that FDI is one of the major factors driving the rapid growth of export from Vietnam. In essence, export and FDI is found as complements. Pontes (2005) establish that there is a non-monotonic relationship between FDI and trade costs. This relationship is positive for high values of trade costs, where FDI and trade behave as complements. But it becomes negative for low values of trade costs, with trade and FDI then behaving as substitutes.

\subsection{Materials and methods}

\subsection{Data sources}


We obtained data of FDI flows to and exports flows from Bangladesh to 21 countries $^{1}$ in current US (\$) over the period 1997-2010 from the Bangladesh Bank and the IMF's Direction of Trade Statistics (CD-ROM), respectively. The real exchange rates of Taka (Bangladesh's currency) against partners' currencies were calculated following Montenegro and Soloaga (2006). Nominal exchange rates and GDP data came from WDI (CD-ROM) and IFS (CD-ROM).

\subsection{Model setting}

The widely used empirical methodology for examining the linkage between FDI and export is the gravity model. Apart from the extensive use of the gravity model in the empirical analysis of international trade and regional integration; a growing number of areas like FDI and migration also heavily rely on the use of the gravity model. Tinbergen (1962) introduced the gravity model, and since then, it has been extensively applied for empirical studies of international blocs. Along with the empirical application of gravity, much work has been done by Anderson (1979); Bergstrand (1985, 1989, 1990); Helpman (1987); Deardorff (1998); and Feenstra et al. (2001) to provide theoretical justification for the model. Helpman (1987) affirmed that the empirical success of the gravity model is evidence supporting the relevance of the imperfect competition model. Deardorff (1998) demonstrated that the gravity model is quite compatible with the traditional Ricardian as well as Heckscher-Ohlin models. Studies by Helpman and Krugman (1985) and Feenstra et al. (2001) showed that both new trade theories of product differentiation as well as the classical Heckscher-Ohlin theory of comparative advantage can provide a theoretical rationale for the gravity model.

In order to assess the linkage between export and FDI, this research applies the following equation:

$$
E X_{i j t}=\beta_{0}+\beta_{1} F D I_{j i t}+\beta_{2} R E X_{i j t}+\beta_{3} D I S T_{i j}+\beta_{4} G D P S U M_{i j t}+\varepsilon_{i j t}
$$

Variables of equation (1) are defined below, while data sources are explained in the appendix.

- $E X_{i j t}$ : The dependent variable $E X_{i j t}$ indicates export flows from Bangladesh (country $i$ ) to country $j$ (importer) at time $t$.

- $\quad F D I_{j i t}$ : Annual inward FDI to Bangladesh from country $j$ at year $t$. Labor abundant countries like Bangladesh usually attract vertical FDI from countries that possess dissimilar resource endowments. In such case, the main driver of inward FDI is to obtain cost advantage by utilizing locally available resources. Vertical from of FDI is expected to raise host country's export because the foreign investor tends to serve the global market from its foreign production. Therefore, FDI variable is supposed to have a positive sign.

- $\quad R E X_{i j t}$ : Real exchange rate between currencies of Bangladesh and its trade partners which were calculated following Montenegro and Soloaga (2006). Bilateral exchange rates indicate the value of one unit of the source country's currency against one unit of a destination country's currency. A rise (fall) in the bilateral exchange rate indicates depreciation (appreciation) of the exporter country's currency. Since depreciation makes exports cheaper, the demand is likely to increase. Hence, depreciation of exchange rate is expected to be positively related to export flows.

- $\quad D I S T_{i j}$ : Geographic distance between source and destination country. In the gravity model, distance is a commonly used proxy for transport costs. Distance between countries is inversely related to export flows and therefore, $\beta_{3}$ should have a negative sign.

- GDPSUM $M_{i j t}$ : The product of GDP of exporter and importer country. GDP is the measure of economic size. The larger the economic size of countries, greater is the involvement in international trade. Thus, the sum of the incomes should be positively linked to export lows.

- $\varepsilon_{i j t}$ is the error term.

\subsection{Estimation technique}

Panel data allows to implement a number of alternative techniques of estimations as such pooled OLS, random effect (RE) and fixed effect (FE). This research applies RE and FE methods which are proven to produce more efficient estimates than the pooled OLS. In order to choose the appropriate estimation technique between RE and FE, Hausman test is conducted. The test produces a Chi 6.83 and P $>$ Chi2 is 0.08 . The insignificant probability value suggests that $\mathrm{RE}$ is the suitable techniques in the current estimations.

\footnotetext{
${ }^{1}$ The sample countries included Canada, China, Denmark, France, Germany, Hong Kong, India, Japan, South Korea, Malaysia, Netherlands, Norway, Pakistan, Saudi Arabia, Singapore, Sri Lanka, Switzerland, Thailand, UAE, UK, and USA.
} 


\subsection{Findings}

Table 1 gives the regression results. The result demonstrates a clear-cut relationship between inward FDI to and export flows from Bangladesh. It is seen that export and FDI are positively related to each other and the relationship is significant at any level of statistical significance. The regression is conducted in the form of natural logarithm and the estimated coefficient indicates that if FDI inflow rises about 9 percent, export increases about one percent. This finding unveils that inward FDI promotes export and thus, the relationship between them is complementary. As a result, it can be argued that if Bangladesh can attract more FDI, it will benefit from higher export growth.

\begin{tabular}{|c|c|c|}
\hline \multicolumn{3}{|c|}{ Table 01: Panel regression estimations } \\
\hline \multirow{2}{*}{ Explanatory variables } & \multicolumn{2}{|c|}{ Coefficients } \\
\hline & RE & FE \\
\hline$F D I$ & 0.11 & 0.07 \\
\hline & $(0.00)^{* * *}$ & $(0.00)^{* *}$ \\
\hline$R E X$ & 0.35 & 0.34 \\
\hline & $(0.00)^{* * *}$ & $(0.00)^{* * *}$ \\
\hline$D I S T$ & $\begin{array}{l}-0.07 \\
(0.14)\end{array}$ & $\begin{array}{l}-0.02 \\
(0.86)\end{array}$ \\
\hline GDPSUM & $\begin{array}{c}0.87 \\
(0.00)^{* * *}\end{array}$ & $\begin{array}{c}0.77 \\
(0.00)^{* * *}\end{array}$ \\
\hline $\mathrm{N}$ & 270 & 245 \\
\hline $\mathrm{R}^{2}$ (within) & 0.70 & 0.70 \\
\hline $\mathrm{R}^{2}$ (between) & 0.88 & 0.87 \\
\hline $\mathrm{R}^{2}$ (overall) & 0.68 & 0.68 \\
\hline Wald Chi & $\begin{array}{c}573 \\
\left(0.00^{* * *}\right)\end{array}$ & - \\
\hline $\mathrm{F}$ & - & $\begin{array}{c}149 \\
\left(0.00^{* * *}\right)\end{array}$ \\
\hline $\begin{array}{l}\text { Notes: i stand for expo } \\
\text { natural logarithms. } \\
\text { P-values are in parenth } \\
\text { respectively. }\end{array}$ & $\begin{array}{l}\text { j for import } \\
\text { dicate signi }\end{array}$ & $\begin{array}{l}\text { e variables are il } \\
\text { and } 1 \% \text { level, }\end{array}$ \\
\hline
\end{tabular}

The real exchange rate variable has the expected positive sign. This means, depreciation of domestic currency against the trade partner's currency, promotes Bangladesh's exports. The estimated coefficient indicates that currency depreciation by one percent causes export growth by 0.35 percent. This result unfolds that exchange rate based liberation of trade is beneficial for Bangladesh. The distance variable has the expected negative sign. However, the estimated result is insignificant at any level of significance. Finally, the sum of GDP of the exporter and importer countries shows a positive significant result. Among all the variables that are included in the regression model, GDPSUM carries the highest marginal effect. The result shows that an increase in GDPSUM by one percent promotes export by 0.87 percent. This finding justifies that high income economies constitute the important export destinations for Bangladesh.

\subsection{Conclusion and policy implications}

There exist two patterns of relationship between FDI and trade flows: complements and substitutes. In the former form of relationship, increased inflow of FDI raises export flows while the latter type of relationship behaves in the opposite direction. From the Heckscher-Ohlin perspective, trade and factor flows are substitutes when the countries involved possess dissimilar factor endowments. On the contrary, trade and factor flows between countries with similar factor endowments but dissimilar technologies are complements.

The empirical exercise of this paper unveils that FDI constitutes one of the significant determinants of exports from Bangladesh. The positive significant relationship between export and capital flows suggests that Bangladesh is the recipient of vertical FDI. In other words, the motive of investment by MNEs is to utilize locally abundant resources and then to serve the world markets from its operations in the host country. Under this circumstance, inward FDI and export behave as a complement which means the growth of the factor flows promotes export growth. The policy implication is simple. Bangladesh needs to promote FDI which in turn, will promote the country's exports.

\section{References}

Anderson, J.E., 1979. A theoretical foundation for the gravity equation. The American Economic Review, 69(1):106116. 
Bangladesh Bank, 2010. Foreign direct investment in Bangladesh, Statistic Department, Survey Report: January-June 2010.

Bergstrand, J.H., 1985. The gravity equation in international trade: some microeconomic foundations and empirical evidence. The Review of Economics and Statistics, 67(3): 474-481. http://dx.doi.org/10.2307/1925976

Bergstrand, J.H., 1989. The generalized gravity equation, monopolistic competition and the factor proportion theory in international trade. The Review of Economics and Statistics, 71(1): 143153.http://dx.doi.org/10.2307/1928061

Bergstrand, J.H., 1990. The Heckscher-Ohlin-Samuelson model, the Linder hypothesis and the determinants of bilateral intra-industry trade. Economic Journal, 100(403):1216-1229.http://dx.doi.org/10.2307/2233969

Deardorff, A.V., 1998. Determinants of bilateral trade: Does gravity work in a neoclassical world? In: J.A. Frankel (Ed.), The Regionalization of the World Economy, pp. 7-32. Chicago: University of Chicago Press.

Dunning, J. H., 1977. The determinants of international production. Oxford Economic Papers, 25(3): 289-330.

Feenstra, R.C., Markusen, J.A., Rose, A.K., 2001. Using the gravity equation to differentiate among alternative theories of trade. The Canadian Journal of Economics, 34(2): 430-447.http://dx.doi.org/10.1111/0008-4085.00082

Helpman, E., 1987. Imperfect competition and international trade: evidence from fourteen industrial countries. Journal of Japanese and International Economics, 1(1):62-81.http://dx.doi.org/10.1016/08891583(87)90027-X

Helpman, E., Krugman P.R., 1985. Market structure and foreign trade: increasing return, imperfect competition and international economy. Cambridge: MIT Press.

Markusen, J.R., 1983. Multinationals, multi-plant economies, and the gains from trade. Journal of International Economics, 16(3-4): 205-226.http://dx.doi.org/10.1016/S0022-1996(84)80001-X

Mundell, R.A., 1957. International trade and factor mobility. The American Economic Review, 47(3):321-335.

Pain, N. and Katharine Wakelin, 1998. Export performance and the role of foreign direct investment. Manchester School of Economic and Social Studies, 66(3): 62-89.http://dx.doi.org/10.1111/1467-9957.66.s.4

Pontes, J.P., 2005. FDI and trade: complements and substitutes. Technical University of Lisbon, Portugal.

Tinbergen, J., 1962. Shaping the world economy: Suggestions for an international economic policy. New York: Twentieth Century Fund.

Vernon, R., 1966. International investment and international trade in the product cycle. Quarterly Journal of Economics, 80(2): 190-207.http://dx.doi.org/10.2307/1880689

Xuan, N.T. and Xing, Y., 2008. Foreign direct investment and exports: the experiences of Vietnam. Economics of Transition, 16(2): 183-197.http://dx.doi.org/10.1111/j.1468-0351.2008.00321.x 